WellBeing International

WBI Studies Repository

6-2018

\title{
Ethical Foundations for the Lethal Management of Double-crested Cormorants (Phalocrocorax auritus) in the Eastern United States: an Argument Analysis
}

\author{
Chelsea Batavia \\ Oregon State University, chelsea.batavia@oregonstate.edu \\ Michael Paul Nelson \\ Oregon State University
}

Follow this and additional works at: https://www.wellbeingintlstudiesrepository.org/ethcbio

Part of the Animal Studies Commons, Bioethics and Medical Ethics Commons, and the Other Ecology and Evolutionary Biology Commons

\section{Recommended Citation}

Batavia, C., \& Nelson, M. P. (2018). Ethical foundations for the lethal management of Double-crested Cormorants (Phalocrocorax auritus) in the eastern United States: an argument analysis. Waterbirds, 41(2), 198-207. https://doi.org/10.1675/063.041.0214

This material is brought to you for free and open access by WellBeing International. It has been accepted for inclusion by an authorized administrator of the WBI Studies Repository. For more information, please contact wbisr-info@wellbeingintl.org.

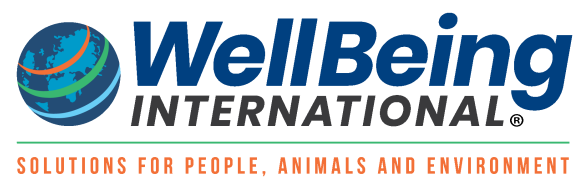




\title{
Ethical Foundations for the Lethal Management of Double-crested Cormorants (Phalocrocorax auritus) in the Eastern United States: an Argument Analysis
}

\author{
Chelsea Batavia* and Michael Paul Nelson \\ Department of Forest Ecosystems and Society, Oregon State University, 321 Richardson Hall, \\ Corvallis, Oregon, 97331, USA
}

*Corresponding author; Email: chelsea.batavia@oregonstate.edu

\begin{abstract}
Lethal management of Double-crested Cormorants (Phalocrocorax auritus) has been implemented in many areas of the United States. In this paper, the philosophical method of argument analysis is used to assess ethical premises underlying the proposition that Double-crested Cormorant populations should be culled to reduce pressures on wild fisheries in the Great Lakes region of the eastern USA. This influential argument has been used to justify the destruction of more than half a million Double-crested Cormorants and hundreds of thousands of their nests and eggs. Three versions of the argument are formulated and assessed. It is shown that each of the arguments presupposes some form of anthropocentrism, an ethical stance considered by many in the scholarly community to be philosophically untenable and ethically inappropriate. It is suggested, consequently, that the arguments analyzed do not constitute an ethically sound basis for lethal management of Double-crested Cormorants in the Great Lakes region of the eastern USA. Received 23 July 2017, accepted 19 September 2017.
\end{abstract}

Key words. - anthropocentrism, argument analysis, Double-crested Cormorant, environmental ethics, humanwildlife conflict, inherent value, lethal management, Phalocrocorax auritus, wildlife management.

Waterbirds 41(2): 198-207, 2018

Competition is integral to ecology. Community development, for example, is largely driven by competitive dynamics between individuals (Tilman 2004), and competition is a primary driver of food web dynamics in ecosystems (Holt and Polis 1997). And yet, although competition is at times a biological necessity, and perhaps an evolutionary imperative, humans (and other species) also demonstrate a parallel capacity for more cooperative modes of social relation (Fehr and Fischbacher 2003; Penner et al. 2005). For example, it is common for humans to share goods and resources with other humans, and non-human beings as well, at times (e.g., by sharing food with pets). However, sharing is not always easy or intuitive in the context of human-wildlife relations, particularly when other species threaten or challenge specific human agendas. Such situations raise complex ethical questions about proper human conduct toward the environment, and particularly wildlife. Are humans obligated to share resources with members of other species, particularly when doing so requires some adjustment to established norms and objectives?

Abstract ethical questions of this sort take on practical importance in the con- text of natural resources and wildlife management. In this paper, we consider lethal management of Double-crested Cormorants (Phalacrocorax auritus; hereafter, cormorants) in the Great Lakes region of the eastern USA. This issue exemplifies some of the ways in which ethical questions come to bear on management decisions. For example, how should conflict between cormorants and humans be handled? As highly conspicuous and efficient fishing birds, cormorants have long been viewed as competitors whose feeding habits threaten valuable commercial and recreational fishery resources (Wild 2012; Wires 2014). Large colonies of cormorants also tend to visibly alter the vegetation of their habitat in ways that might adversely affect other bird and wildlife species, along with scenic or aesthetic qualities of the landscape enjoyed by humans (Wires 2014). Although formally protected under the Migratory Bird Treaty Act of 1918 (U.S. Fish and Wildlife Service 2009), in many States of the USA, cormorants have been legally killed under the 1998 Aquaculture Depredation Order and the 2003 Public Resource Depredation Order, which, until recently, have permitted the "take" of cormorants perceived to damage environ- 
mental or economic resources that humans want or need (U.S. Fish and Wildlife Service 2003a). These regulations set an important precedent for the management of not only cormorants, but fish-eating birds as a group, since many fish-eating species interact with resources in ways similar to cormorants.

For years, the U.S. Fish and Wildlife Service has enacted extensive lethal management activities across the eastern USA, largely responding to the perception that cormorant fishing habits threaten human interests in wild fisheries (U.S. Fish and Wildlife Service 2014a; Wires 2014). Since the first depredation order was established in 1998, well over half a million cormorants and hundreds of thousands of nests and eggs have been destroyed (U.S. Fish and Wildlife Service 2014a). As of May 2016, following a legal suit filed by Public Employees for Environmental Responsibility (Case 1:14-cv-01807-JBD), the U.S. Fish and Wildlife Service was found to be in violation of the National Environmental Policy Act with its most recent renewals of the Aquaculture Depredation Order and the Public Resource Depredation Order (U.S. Fish and Wildlife Service 2014b). Both orders have since been suspended, and the U.S. Fish and Wildlife Service was ordered to conduct a "new and legally adequate" environmental assessment or environmental impact statement to consider multiple management alternatives.

As the U.S. Fish and Wildlife Service initiates this process, it is critical that the agency take not only relevant scientific, political, and socioeconomic factors into consideration, but also ethical ones. Despite the magnitude of lethal cormorant management in the eastern USA, there has to date been no critical assessment of its ethical appropriateness (Wires 2014). Fortunately, such challenging ethical issues can be addressed in a rigorous, systematic manner using established methods of philosophical analysis. Lethal management of cormorants has been employed for certain reasons, which can be constructed formally as arguments. By explicitly formulating and analyzing arguments, unfounded assumptions, false information, and inappropriate moral precepts are laid open to rational critique. We use argument analysis to evaluate one highly influential argument underpinning past and ongoing proposals for lethal cormorant management in the Great Lakes region of the USA. The aims in this paper are twofold: 1) to highlight some of the problematic claims underlying lethal cormorant management in this region; and 2) to demonstrate the value of argument analysis as a method to systematically reason through controversial issues in natural resources and wildlife management.

Methods

Argument analysis has only recently been applied to natural resources and related fields (Nelson and Vucetich 2009; Vucetich and Nelson 2017), but it is well established in philosophical tradition and traces its roots to Greek antiquity with the birth of formal logic (Jaquette 2006). In its most basic form, an argument can be formulated as a set of premises $(\mathrm{P})$ that lead to a conclusion (C). For example:

P1. All cormorants are black birds.

P2. All black birds eat fish.

C. Therefore, all cormorants eat fish.

Once formulated, the argument can be assessed for soundness. A sound argument must meet two criteria. First, the premises must logically entail the conclusion of the argument. If an argument meets this first criterion, it is valid but not necessarily sound. To be sound the argument must also meet the second criterion, namely that all of its premises are true. The argument above is valid (since, by deductive logic, if we accept both premises we must also accept the conclusion), but $\mathrm{P} 2$ is clearly untrue, so the argument is not sound. And yet, we know the conclusion is accurate. This highlights the important caveat that even if an argument is unsound, the position it supports is not necessarily wrong. A thorough argument analysis will consider a full spectrum of arguments to assess whether a given position is rationally justified by any of the arguments made in its defense.

The example above is a relatively simple descriptive argument. More commonly in natural resources and wildlife management, people advance normative arguments (i.e., arguments that are prescriptive, rather than descriptive). Normative arguments must contain at least one normative premise to be valid. A normative premise might explicitly state how things "should" or "ought to" be, but it may take other forms as well (e.g., by asserting notions of good or bad, right or wrong, justice, or value). When stated in these latter forms, we might consider the premise not only normative but also distinctly ethical.

A set of exclusively descriptive premises does not logically entail a normative conclusion, since what "is" observed does not on its own suggest what "ought" to be (Hume 2000). For example, it is impossible to argue: 
P1. Cormorants are black birds. (descriptive)

C. Therefore, we should kill cormorants. (normative)

The argument requires an additional normative premise:

P1. Cormorants are black birds. (descriptive)

P2. We should kill all black birds. (normative)

C. Therefore, we should kill cormorants. (normative) Now the chain of inference is valid, since the two premises necessarily entail the conclusion. However, we still must evaluate the premises for truth. Assessing the "truth" of normative premises can be more challenging than assessing the truth of descriptive premises, which are often scientifically and empirically verifiable. We generally try to evaluate whether a normative premise is "appropriate" rather than true. Though sometimes complex and highly controversial, judgments of appropriateness can in many cases be made simply by referring to common morality, or even common sense. For example, the unqualified assertion "we should kill all black birds" would be justifiable only on grounds of superstition or intolerance, neither generally accepted as a basis for a moral position, at least in contemporary Western society. Therefore, P2 can be considered inappropriate, rendering the argument unsound.

Prior to analysis, arguments must first be identified and selected, a process that can be carried out in different ways. For example, Jager et al. (2016) used relevant media coverage to identify and analyze arguments for and against management of Mute Swans (Cygnus olor) in Michigan, USA. For the present analysis, we relied on a small group of colleagues with expertise and experience in cormorant management in the USA. With these colleagues, we compiled a table of the most influential reasons people use to support or oppose lethal management of cormorants
(Table 1). To conduct a thorough analysis, each reason in Table 1 could be formulated and evaluated as a separate argument. Here, we analyze one set of arguments, which generally state that lethal management should be used because cormorant populations threaten valuable goods and resources, including wild fisheries, aquaculture, and ecosystem health. Since space prevents us from analyzing arguments in each of these contexts, we focus on wild fisheries, a central and long-standing locus of conflict between humans and cormorants in the Great Lakes region of the USA (Wires 2014).

\section{RESUlts}

We identified three versions of the wild fisheries argument, each ethically distinguishable from the others in subtle but important ways. The first version can be formulated as follows:

P1. Wildlife that impede humans from satisfying their preferences are nuisances.

P2. Cormorants impede humans from satisfying their preferences in wild fisheries.

C1. Therefore, cormorants are nuisances.

P3. To allow humans to satisfy their preferences, wildlife nuisances should be controlled by whichever means are most practical and effective.

Table 1. Reasons for and against lethal management of Double-crested Cormorants in the Great Lakes region, USA. Reasons were developed by a small group of experts who specialize in the study of Double-crested Cormorants, and are based on their collective experience with lethal management of these birds in the USA.

\begin{tabular}{|c|c|}
\hline Reasons for Lethal Management & Reasons against Lethal Management \\
\hline $\begin{array}{l}\text { Lethal management of cormorants protects goods } \\
\text { enjoyed by humans (wild fisheries, aquaculture, } \\
\text { ecosystem health) }\end{array}$ & $\begin{array}{l}\text { Lethal management of cormorants will have nega- } \\
\text { tive impacts on ecosystems }\end{array}$ \\
\hline Cormorants are greedy or voracious & $\begin{array}{l}\text { Cormorants are living creatures, worthy of moral } \\
\text { consideration }\end{array}$ \\
\hline Cormorants are invasive or destructive & Cormorants are a natural part of the ecosystem \\
\hline $\begin{array}{l}\text { Lethal management of cormorants imparts a sense } \\
\text { of control over fish stock losses }\end{array}$ & $\begin{array}{l}\text { Cormorants are not responsible for fish stock losses } \\
\text { - it is unjust to blame them, and a distraction from } \\
\text { the real issue }\end{array}$ \\
\hline Cormorants are appropriate targets for hunting & Lethal management of cormorants is ineffective \\
\hline $\begin{array}{l}\text { Cormorants exceed human tolerance levels (so- } \\
\text { cial, cultural, or wildlife carrying capacity) }\end{array}$ & $\begin{array}{l}\text { Slippery slope: lethal management sets a precedent } \\
\text { that risks undermining other environmental laws }\end{array}$ \\
\hline $\begin{array}{l}\text { Lethal management will not compromise popula- } \\
\text { tion viability }\end{array}$ & $\begin{array}{l}\text { The outcome of lethal management is uncertain } \\
\text { and runs contrary to the precautionary principle }\end{array}$ \\
\hline $\begin{array}{l}\text { Lethal management is the only way to handle hu- } \\
\text { man-wildlife conflict }\end{array}$ & There are other ways to resolve human-wildlife conflict \\
\hline $\begin{array}{l}\text { Lethal management is necessary to appease certain } \\
\text { social sectors }\end{array}$ & There is no good reason to use lethal management \\
\hline
\end{tabular}


$\mathrm{P} 4$. Lethal management is the most practical and effective means for controlling cormorants.

C2. Therefore, cormorants should be controlled by lethal management.

$\mathrm{P} 1$ and $\mathrm{P} 3$ situate this argument in a narrow anthropocentric, utilitarian worldview. Based on the metaphysical belief that humans are categorically distinct from and superior to all other types of beings, the narrow anthropocentric view presumes that nonhuman beings, including wildlife, are valuable only to the extent that they satisfy human preferences (Norton 1984; Goralnik and Nelson 2012). Following from this view, narrow anthropocentrism assumes humans are justified in using wildlife in whichever way maximizes human welfare. On this view, it is appropriate to sustain or promote wildlife populations that have some utility value for humans, but it is also appropriate to control or even eradicate wildlife populations that have no such utility value, particularly when they actively prevent humans from enjoying the utility value of other goods or resources.

Narrow anthropocentrism has been widely rejected as a basis for management, being linked to extractive and exploitative use of wildlife and natural resources (White 1967; Callicott 1990; Norton 1992). It has also been critiqued philosophically for being predicated on flawed assumptions that only humans possess certain characteristics, such as sentience, consciousness, or rationality, which are used as markers of human superiority over other types of beings (Routley and Routley 1979). With the recognition that some nonhuman beings possess these same characteristics (and some human beings do not possess these characteristics), environmental ethicists argue that it is arbitrary and rationally inconsistent to elevate humans categorically above nonhumans, or at least those who possess the characteristics in question (Routley and Routley 1979). Others still have criticized the choice of characteristics themselves as human-biased, socially constructed, and rationally indefensible criteria for moral standing (Taylor 1981; Plumwood 1993).
Although there is wide recognition in the scholarly community that narrow anthropocentrism is environmentally damaging, philosophically untenable, and ethically inappropriate, it remains influential as a normative basis for wildlife management, including lethal management of cormorants in the eastern USA. People in the Lake Champlain region of the USA, for example, have expressed preferences for less abundant cormorant populations, regarding the birds, at observed population levels, as pests (Kuentzel et al. 2012). These attitudes are associated with perceived competition between cormorants and anglers, and also linked to support for lethal management activities (Kuentzel $e t$ al. 2012).

The second version of the wild fisheries argument exemplifies a broader form of anthropocentrism than the first, by acknowledging a spectrum of human benefits beyond purely economic or utility values (Norton 1984; Goralnik and Nelson 2012). This version of the argument can be formulated as follows:

P1. Wild fisheries provide benefits for humans.

P2. Cormorant populations also provide benefits for humans.

P3. Cormorant predation compromises the benefits wild fisheries provide for humans.

P4. Wildlife management should sustain all the benefits that wildlife provide for humans.

P5. Using lethal management to control cormorant predation sustains the benefits that both wild fisheries and cormorant populations provide for humans.

C. Therefore, lethal management should be used to control cormorant predation.

The broad anthropocentric view, advanced decades ago by environmental ethicist Bryan Norton (Norton 1991), has become influential of late in the prevalent ecosystem services framework for management and conservation, which expands the notion of a human "benefit" to include 
indirect or intangible goods that are supported by ecosystem processes and functions (Costanza et al. 2017). In many cases, lethal management of cormorants has been informed by a similarly expansive sense of human benefits. For example, the environmental assessment conducted by the U.S. Fish and Wildlife Department in the state of Michigan, USA, notes, "Wildlife populations provide a range of social and economic benefits... related to consumptive and non-consumptive use" (U.S. Department of Agriculture 2011). With the understanding that cormorants do have value for some people, even if their particular type of value (e.g., cultural or existence value) cannot be reduced to a utility or preference, lethal management has been framed as an effort to balance the multiple values of wildlife for humans.

As stated in P5, lethal management to control cormorant populations may protect the benefits humans derive from both fisheries and cormorants if we assume the particular types of values associated with cormorants would still be provided by less abundant populations. If this is true, and if we accept the broad anthropocentric stance adopted in $\mathrm{P} 4$, the conclusion here may be justified. However, this version of the argument neglects the possibility that the cormorants being culled may also have value in themselves. If broad anthropocentrism avoids some of the practical problems (i.e., exploitation and resource degradation) linked to the narrower anthropocentric stance (White 1967; Norton 1991), it still posits human beings and their interests as the measure of all value in the world. As such, it can be critiqued on the philosophical and ethical grounds of arbitrariness, inconsistency, and inappropriateness noted above.

Against anthropocentrism, many in the scholarly community have argued that wildlife, either individually or collectively, also possess inherent value (i.e., value for their own sake) (Taylor 1981; Agar 2001; Smith 2016). Inherent value, in turn, is used as a basis for the argument that wildlife ought to be granted direct moral standing, obligating humans, as moral agents, to view and treat them as more than instrumental means to human ends (Taylor 1981; Rolston 1988). If these arguments are sound, a claim like P4 suggesting wildlife should be managed only for and as human benefits, without considering their inherent value, would be ethically inappropriate. This leads to a third version of the wild fisheries argument, which can be formulated as follows:

P1. Cormorant predation on commercial/recreational fish stocks competes with human interests, generating conflict between cormorants and humans.

P2. Conflict between cormorants and humans should be reduced.

P3. Lethal management will reduce cormorant predation on commercial/ recreational fish stocks.

P4. Reducing cormorant predation on commercial/recreational fish stocks will reduce conflict between cormorants and humans.

C1. Therefore, lethal management will reduce conflict between cormorants and humans.

P5. Lethal management entails intentionally killing cormorants.

P6. As living beings with inherent value, cormorants should not be intentionally killed without justification.

P7. Reducing conflict between cormorants and humans justifies intentionally killing cormorants.

C2. Therefore, cormorants should be intentionally killed to reduce conflict between cormorants and humans.

Before addressing the ethical premises of this third version of the argument, we briefly comment on the empirical premises, since they also bear on the soundness of the argument.

The claim made in P1 (which also appeared, in slightly different forms, in P2 of the first version and $\mathrm{P} 3$ of the second version of the argument) is contested. Wires (2014) summarizes a large body of research on the impacts of cormorant predation on highvalue fishery stocks. Most evidence indicates 
that cormorants do not primarily feed on fish species that are valued by anglers and commercial fishermen or fisherwomen (Diana $e t$ al. 2006; Dalton et al. 2009). But cormorants are also widely considered generalist and opportunistic feeders (Wires 2014), adapting to geographic and seasonal fluctuations in prey, which might sometimes include fish valued by anglers and commercial fishermen or fisherwomen (Lantry et al. 2002; Rudstam et al. 2004; Fielder 2008). Thus, we cannot at present say with certainty whether or under what circumstances P1 is true or not true. It is certainly true, however, that cormorant predation is perceived to compete with human interests, and this perceived competition has indeed contributed to conflict between cormorants and humans in the eastern USA (Kuentzel et al. 2012; Wires 2014). Proceeding to P3, there is evidence associating lethal management of cormorants with recovery in valued fish populations (Fielder 2010; Schultz et al. 2013; Johnson et al. 2015). However, these findings are context-specific, and the research has been critiqued for the presence of confounding variables and study design biases (Diana 2010; Schultz et al. 2013; Johnson et al. 2015). Therefore, the truth of P3 also remains unclear. The last empirical premise that merits commentary is $\mathrm{P} 4$ (since P5 is a non-controversial statement of fact). In the growing body of work on human-wildlife conflict (Seoraj-Pillai and Pillay 2017), researchers have found that conflict does not necessarily dissipate once damages caused by wildlife, or perceived to be caused by wildlife, have ceased (Dickman 2010). Drivers of human conflicts with cormorants, and wildlife in general, are many and complex (Dickman 2010). Conflict with cormorants in the Great Lakes region of the USA, for example, is proximately related to perceived competition over wild fisheries, but there is also a long history of superstition around and intolerance toward cormorants, neither of which is necessarily based on cormorant predation habits per se (Wires 2014). Therefore, the initial conclusion (C1) that reducing predation-related competition will also reduce conflict may not be supported.
Turning now to the ethical premises, P6 marks the most obvious divergence from previous versions of the argument. $\mathrm{P} 6 \mathrm{ex}-$ presses a claim about the inherent value of cormorants that can be found in both the Final Environmental Impact Statement and the Final Rule for the 2003 Public Resource Depredation Order (U.S. Fish and Wildlife Service 2003a, 2003b). The premise here expresses a biocentric perspective attributing inherent value to cormorants as living beings (Goralnik and Nelson 2012), but could also be expressed from a zoocentric perspective attributing inherent value to cormorants as sentient animals.

The important point to note is that, whether as sentient animals or as living beings, cormorants are recognized as ends in themselves, whose value extends beyond any value they provide for humans. From this follows the reasonable and generally noncontroversial ethical claim that entities with inherent value should only be killed if there is good reason to do so.

P7 cites conflict reduction as justification for intentionally killing cormorants. Ethicists call this sort of claim "consequentialist," in the sense that it appeals to the outcomes, or consequences, of an act (in this case, lethal management) to judge whether the act is right or wrong (Sinnott-Armstrong 2015). In the context of the argument, for justification $\mathrm{P} 7$ relies on $\mathrm{P} 2$ before it, which established conflict reduction as a worthy outcome. With broad consensus that resolution or at least mitigation of human-wildlife conflict is a desirable goal (Treves et al. 2009), P2 can be considered appropriate in a general sense. However, even a worthy end may not justify any means used to achieve it (Nelson et al. 2016). As such, establishing conflict reduction as a worthy end, in P2, does not, on its own, justify the more specific, comparative claim that its value as an end supersedes the inherent value of the cormorants sacrificed in efforts to reduce conflict.

Justifying P7 requires us to weigh the relative benefits of conflict resolution against the costs, and particularly the costs in cormorant lives. Assessments of this sort, which seek to compare values measured on different scales 
(if measurable at all), are challenging, and their accuracy is a matter of some debate (Spash 2000; Gómez-Baggethun et al. 2010). But P7 can also be evaluated conceptually by more closely examining the meaning of "conflict," as it is being used here. In the human-wildlife context, "conflict" has been defined in different ways, but most commonly refers to damages caused by wildlife to human goods or resources (Peterson et al. 2010). Conflict, in this sense, is defined specifically from the perspective of humans (i.e., it is anthropocentric). At first glance, this connotation of "anthropocentric" may appear to be non-problematic; indeed, to the extent that we can only live and experience from our own human perspective, it is impossible for us to be anything but anthropocentric (Goralnik and Nelson 2012). However, conflict is not only being defined from the human perspective in this ontologically anthropocentric sense, but also relative to and, critically, in the service of human values and interests in an ethically anthropocentric sense (Goralnik and Nelson 2012). To understand why this is the case, consider for a moment how "conflict" would be defined if we were to adopt a cormorant's perspective. As generalists, cormorants are relatively flexible and can adapt to prey availability, or lack thereof, if and as it fluctuates with human fishing operations (Wires 2014). As such, for cormorants "conflict" is not directly related to resource limitations as it is for humans in the Great Lakes region of the USA. Instead, conflict, as a cormorant might view it, arises out of the hazing, egg oiling, nest disruption, and shooting that, until recently, have been widely enacted to control their populations. It is striking to notice that alleviating conflict, as viewed from a human perspective, actually causes and perpetuates conflict, as viewed from a cormorant perspective. It is also important to note that the benefits of lethal management accrue entirely to humans, while costs are born entirely by cormorants. Therefore, even were it demonstrated, in a quantitative sense, that the net benefits of lethal management and conflict resolution exceed net costs, the distribution of costs and benefits is overwhelmingly skewed to favor human interests. If cormorants were regarded and valued not merely as means, but also as ends in themselves, their interests could not, in good conscience, be so completely overlooked.

As such, P6 either misinterprets the meaning and implications of "inherent value" or invokes it as a rhetorical tool to deflect criticism from certain social sectors. Either way, this analysis suggests $\mathrm{P} 6$ can best be explained as a spurious non-anthropocentric premise in an otherwise anthropocentric argument for lethal management.

\section{Discussion}

This analysis, which examined three slightly different arguments supporting cormorant management in the eastern USA, demonstrates that all three arguments are predicated on an anthropocentric ethical position, which has been broadly refuted on philosophical and, in some cases, practical grounds. We suggest lethal control of cormorants, or any wildlife population, predicated on anthropocentric claims or propositions is not ethically appropriate and should not be accepted as a sound basis for ongoing lethal management activities.

It could be argued that we formulated these arguments specifically to represent an anthropocentric stance. There is indeed some discretion in the precise wording and structure of the arguments presented in this paper, and certainly we acknowledge that our own values informed the interpretation of the arguments presented herein. We do not support the extensive program of lethal management that has been enacted across the eastern USA for many years, in part because we feel it rests on infirm anthropocentric ethical foundations. However, we also point to evidence in the extent and extremity of lethal management that suggests our representation of these arguments, and our claim that the inherent value of cormorants has not genuinely been taken into consideration, are defensible.

For example, as ruled by the District of Columbia District Court in 2016 (Case 
1:14-cv-01807-JBD), the U.S. Fish and Wildlife Service has failed to take the requisite "hard look" at impacts of lethal management on cormorants, as mandated under the National Environmental Policy Act (U.S. Office of NEPA Policy and Compliance 2017). If managing agencies have neglected their legal imperative to seriously consider the interests of cormorants, it seems unlikely that they recognize a parallel moral imperative to do the same. The magnitude of cormorant management across the eastern USA is also telling. Over 500,000 cormorants were legally killed between 1999 and 2012, as permitted by Federal order (U.S. Fish and Wildlife Service 2014a). Assuming yearly averages remained more or less constant from 20132015, this figure now likely exceeds 600,000 (U.S. Fish and Wildlife Service 2014a), even without accounting for other methods of cormorant harassment and control, such as nest destruction and egg oiling. We can also consider how targets have been set for lethal management. At the national level, the Final Environmental Impact Statement for the 2003 Public Resource Depredation Order proposed that roughly $8 \%$ of the U.S. population of cormorants would be killed, approximately 160,000 individuals (U.S. Fish and Wildlife Service 2003b). These targets were calculated based on records of cormorant depredation permits issued historically, prior to the Public Resource Depredation Order (U.S. Fish and Wildlife Service 2003b). Although this target certainly reflects public perceptions of cormorant predation and its effects on fishery stocks, which may or may not be accurate, it is not clearly based on scientifically informed estimates of the number of cormorants that would actually need to be removed to achieve recovery objectives for fisheries. Targets defined at the State level are also revealing. The environmental assessment for cormorant management in the State of Michigan, USA, for example, dictates that a minimum of 5,000 breeding pairs of cormorants should be maintained statewide, a figure calculated to ensure overall cormorant population viability, and that no more than 15,500 cormorants may be killed in a given year (U.S. Depart- ment of Agriculture 2011). Management targets, in other words, prescribe the maximum number of cormorants that can be killed, rather than the minimum number that must be killed, to achieve defined fisheries objectives. This would be unfathomable as a rubric for governance of human societies or mitigation of inter-human conflicts. We suggest the calculation of management targets, and the thought processes underpinning them, would be radically different if the inherent value of cormorants was truly recognized.

Cormorants are currently experiencing a population resurgence bringing them close to historic abundances (Wires and Cuthbert 2006), and could probably remain viable even at lower local and national population levels. Thus, the persistence of the species is not immediately at stake in deciding whether or not to continue lethal management. We suggest the more pressing issue is whether, in killing cormorants to eradicate competition (or perceived competition) with humans, we are appropriately sharing common resources. Just as humans, individually and as societies, decide when and how to share with other humans, so too must we decide when and how we are obligated to share with non-human entities, including cormorants. There are unfortunately no simple rules to guide such challenging moral decisions, and many questions remain to be explored as we consider what it means (ecologically, socially, and philosophically) for humans to share the earth's resources with other life forms. For now, the more basic point we hope to emphasize is that the ability, and at times imperative, to share should not be restricted by default to inter-human relations. Instead, perhaps we ought to begin with the assumption that we are morally obligated to share with non-humans, like cormorants, and that therefore we should share with non-humans unless there is a sound reason not to do so.

We focused primarily on only one set of arguments here, but the reasons listed in Table 1 raise other interesting and important ethical questions as well. Examples include how to appropriately balance the wellbeing of individual entities with the good of the collective ecosystem (Vucetich and Nelson 
2007), and to what extent humans should respect or uphold the "naturalness" of ecological systems (Anderson 1991). Particularly, as the U.S. Fish and Wildlife Service begins to develop and assess management alternatives, we recommend argument analysis as a way to structure thorough assessment of not only the scientific but also the ethical underpinnings and implications of different proposals. Having analyzed only one argument in this paper, we cannot rule out the possibility that lethal cormorant management in the eastern USA may be supported by a different argument or set of arguments. However, if ongoing proposals for lethal management are in fact being supported solely or primarily by the arguments examined in this paper, we suggest there is good reason for the U.S. Fish and Wildlife Service to seriously reconsider reinstating any broad scale program of lethal cormorant management unless or until it is justified by an alternative line of reasoning that is both scientifically and ethically sound.

\section{ACKNOWLEDGMENTS}

Support for this work was provided by the H. J. Andrews Experimental Forest research program, funded by the National Science Foundation's Long-Term Ecological Research Program (DEB 1440409), with additional financial support from the Achievement Rewards for College Scientists (ARCS) Foundation. The authors wish to thank D. D. Roby, D. E. Lyons, D. N. Carss, and D. V. Weseloh for sharing their advice and expertise at key stages throughout the preparation of this paper, and especially L. R. Wires for her leadership and support. The authors also thank two anonymous reviewers for providing helpful feedback on an earlier version of the manuscript.

\section{Literature Cited}

Agar, N. 2001. Life's intrinsic value. Columbia University Press, New York, New York.

Anderson, J. E. 1991. A conceptual framework for evaluating and quantifying naturalness. Conservation Biology 5: 347-352.

Callicott, J. B. 1990. Whither conservation ethics? Conservation Biology 4: 15-20.

Costanza, R., R. de Groot, L. Braat, I. Kubiszewski, L. Fioramonti, P. Sutton, S. Farber and M. Grasso. 2017. Twenty years of ecosystem services: how far have we come and how far do we still need to go? Ecosystem Services 28: 1-16.
Dalton, C. M., D. Ellis and D. M. Post. 2009. The impact of Double-crested Cormorant (Phalacrocorax auritus) predation on anadromous alewife (Alosa pseudoharengus) in south-central Connecticut, USA. Canadian Journal of Fisheries and Aquatic Sciences 66: 177-186.

Diana, J. S. 2010. Should cormorants be controlled to enhance yellow perch in Les Cheneaux Islands? A comment on Fielder. Journal of Great Lakes Research 36: 190-194.

Diana, J. S., S. Maruca and B. Low. 2006. Do increasing cormorant populations threaten sportfishes in the Great Lakes? A case study in Lake Huron. Journal of Great Lakes Research 32: 306-320.

Dickman, A. J. 2010. Complexities of conflict: the importance of considering social factors for effectively resolving human-wildlife conflict. Animal Conservation 13: 458-466.

Fehr, E. and U. Fischbacher. 2003. The nature of human altruism. Nature 425: 785-791.

Fielder, D. G. 2008. Examination of factors contributing to the decline of the yellow perch population and fishery in Les Cheneaux Islands, Lake Huron, with emphasis on the role of Double-crested Cormorants. Journal of Great Lakes Research 34: 506-523.

Fielder, D. G. 2010. Response of yellow perch in Les Cheneaux Islands, Lake Huron to declining numbers of Double-crested Cormorants stemming from control activities. Journal of Great Lakes Research 36: 207-214.

Gómez-Baggethun, E., R. de Groot, P. L. Lomas and C. Montes. 2010. The history of ecosystem services in economic theory and practice: from early notions to markets and payment schemes. Ecological Economics 69: 1209-1218.

Goralnik, L. and M. P. Nelson. 2012. Anthropocentrism. Pages 145-155 in Encyclopedia of Applied Ethics, 2nd ed. (R. Chadwick, Ed.). Academic Press, San Diego, California.

Holt, R. D. and G. A. Polis. 1997. A theoretical framework for intraguild predation. American Naturalist 149: 745-764.

Hume, D. 2000. A treatise on human nature. (D. F. Norton and M. J. Norton, Eds.). Oxford University Press, New York, New York.

Jager, C., M. P. Nelson, L. Goralnik and M. Gore. 2016. Michigan mute swan management: a case study to understand contentious natural resource management issues. Human Dimensions of Wildlife 21: 189-202.

Jaquette, D. (Ed.). 2006. A philosophical companion to logic, 2nd ed. Blackwell, Malden, Massachusetts.

Johnson, J. H., R. D. McCullough, J. F. Farquhar and I. Mazzocchi. 2015. Little Galloo Island, Lake Ontario: two decades of studies on the diet, fish consumption, and management of Double-crested Cormorants. Journal of Great Lakes Research 41: 652-658.

Kuentzel, W. E., D. E. Capen, Z. L. Richards and B. R. Higgins. 2012. Attitude strength and social acceptability of cormorant control programs on Lake Champlain. Journal of Great Lakes Research 38: 141-149. 
Lantry, B. F., T. H. Eckert, C. P. Schneider and J. R. Chrisman. 2002. The relationship between the abundance of smallmouth bass and Double-crested Cormorants in the eastern basin of Lake Ontario. Journal of Great Lakes Research 28: 193-201.

Nelson, M. P. and J. A. Vucetich. 2009. On advocacy by environmental scientists: what, whether, why, and how. Conservation Biology 23: 1090-1101.

Nelson, M. P., J. T. Bruskotter, J. A. Vucetich and G. Chapron. 2016. Emotions and the ethics of consequence in conservation decisions: lessons from Cecil the Lion. Conservation Letters 9: 302-306.

Norton, B. G. 1984. Environmental ethics and weak anthropocentrism. Environmental Ethics 6: 131-148.

Norton, B. G. 1991. Toward unity among environmentalists. Oxford University Press, New York, New York.

Norton, B. G. 1992. Epistemology and environmental values. Monist 75: 208-226.

Penner, L. A., J. F. Dovidio, J. A. Piliavin and D. A. Schroeder. 2005. Prosocial behavior: multilevel perspectives. Annual Review of Psychology 56: 365-392.

Peterson, M. N., J. L. Birckhead, K. Leong, M. J. Peterson and T. R. Peterson. 2010. Rearticulating the myth of human-wildlife conflict. Conservation Letters 3: 74-82.

Plumwood, V. 1993. Feminism and the mastery of nature. Routledge, New York, New York.

Rolston, H., III. 1988. Environmental ethics: duties to and values in the natural world. Temple University Press, Philadelphia, Pennsylvania.

Routley, R. and V. Routley. 1979. Against the inevitability of human chauvinism. Pages 36-59 in Ethics and Problems of the 21st Century (K. E. Goodpaster and K. M. Sayre, Eds.). University of Notre Dame Press, Notre Dame, Indiana.

Rudstam, L. G., A. J. VanDeValk, C. M. Adams, J. T. H. Coleman, J. L. Fornley and M. E. Richmond. 2004. Cormorant predation and the population dynamics of walleye and yellow perch in Oneida Lake. Ecological Applications 14: 149-163.

Schultz, D. W., A. J. Carlson, S. Mortensen and D. L. Pereira. 2013. Modeling population dynamics and fish consumption of a managed Double-crested Cormorant colony in Minnesota. North American Journal of Fisheries Management 33: 1283-1300.

Seoraj-Pillai, N. and N. Pillay. 2017. A meta-analysis of human-wildlife conflict: South African and global perspectives. Sustainability 9: 34 .

Sinnott-Armstrong, W. 2015. Consequentialism. The Stanford Encyclopedia of Philosophy (E. N. Zalta, Ed.). https://plato.stanford.edu/archives/win2015/entries/consequentialism/, accessed 11 October 2017.

Smith, I. A. 2016. The intrinsic value of endangered species. Routledge, New York, New York.

Spash, C. L. 2000. Ecosystems, contingent valuation and ethics: the case of wetland re-creation. Ecological Economics 34: 195-215.

Taylor, P. W. 1981. The ethics of respect for nature. Environmental Ethics 3: 197-218.
Tilman, D. 2004. Niche tradeoffs, neutrality, and community structure: a stochastic theory of resource competition, invasion, and community assembly. Proceedings of the National Academy of Science 101: 10854-10861.

Treves, A., R. B. Wallace and S. White. 2009. Participatory planning of interventions to mitigate human-wildlife conflict. Conservation Biology 23: 1577-1587.

U.S. Department of Agriculture. 2011. Final environmental assessment: Double-crested Cormorant damage management in Michigan. Unpublished report, U.S. Department of Agriculture, Wildlife Services, Okemos, Michigan.

U.S. Fish and Wildlife Service. 2003a. Migratory bird permits; regulations for Double-crested Cormorant management. Federal Register 68: 58022-58037.

U.S. Fish and Wildlife Service. 2003b. Final environmental impact statement: Double-crested Cormorant management in the United States. Unpublished report, U.S. Department of the Interior, Fish and Wildlife Service, Arlington, Virginia.

U.S. Fish and Wildlife Service. 2009. Migratory Bird Treaty Act of 1918 (16 U.S.C. 703-712). https:// www.fws.gov/le/USStatutes/MBTA.pdf, accessed 21 October 2017.

U.S. Fish and Wildlife Service. 2014a. Final environmental assessment: management of Double-crested Cormorants under CFR 21.47 and 21.48. Unpublished report, U.S. Department of the Interior, Fish and Wildlife Service, Arlington, Virginia.

U.S. Fish and Wildlife Service. 2014b. Migratory bird permits; extension of expiration dates for Doublecrested Cormorant depredation orders. Federal Register 79: 30474-30483.

U.S. Office of NEPA Policy and Compliance. 2017. NEPA of 1969 (42 U.S.C. 4321-4347). Washington, D.C. https://energy.gov/sites/prod/files/nepapub/nepa documents/RedDont/Req-NEPA.pdf, accessed 27 October 2017.

Vucetich, J. A. and M. P. Nelson. 2007. What are 60 warblers worth? Killing in the name of conservation. Oikos 116: 1267-1278.

Vucetich, J. A. and M. P. Nelson. 2017. Wolf hunting and the ethics of predator control. Pages 411-429 in The Oxford Handbook of Animal Studies (L. Kalof, Ed.). Oxford University Press, Oxford, U.K.

White, L., Jr. 1967. The historical roots of our ecologic crisis. Science 155: 1203-1207.

Wild, D. 2012. The Double-crested Cormorant: symbol of ecological conflict. University of Michigan Press, Ann Arbor, Michigan.

Wires, L. R. 2014. The Double-crested Cormorant: plight of a feathered pariah. Yale University Press, New Haven, Connecticut.

Wires, L. R. and F. J. Cuthbert. 2006. Historic populations of the Double-crested Cormorant (Phalocrocorax auritus): implications for conservation and management in the 21st century. Waterbirds 29: 9-37. 